\title{
Obesity and Erectile Dysfunction: From Bench to Clinical Implication
}

\author{
Ki Hak Moon ${ }^{1}$ D , So Young Park² ${ }^{2}$, Yong Woon Kim² ${ }^{2}$ \\ Departments of ${ }^{1}$ Urology and ${ }^{2}$ Physiology, Yeungnam University College of Medicine, Daegu, Korea
}

\begin{abstract}
Obesity is a major public health issue worldwide and is frequently associated with erectile dysfunction (ED). Both conditions may share an internal pathologic environment, also known as common soil. Their main pathophysiologic processes are oxidative stress, inflammation, and resultant insulin and leptin resistance. Moreover, the severity of ED is correlated with comorbid medical conditions, including obesity. Therefore, amelioration of these comorbidities may increase the efficacy of ED treatment with phosphodiesterase 5 inhibitors, the first-line medication for patients with ED. Although metformin was originally developed as an insulin sensitizer six decades ago, it has also been shown to improve leptin resistance. In addition, metformin has been reported to reduce oxidative stress, inflammatory response, and body weight, as well as improve ED, in animal and human studies. Moreover, administration of a combination of metformin and phosphodiesterase 5 inhibitors improves erectile function in patients with ED who have a poor response to sildenafil and are insulin resistant. Thus, concomitant treatment of metabolic derangements associated with obesity in patients with ED who are obese would improve the efficacy and reduce the refractory response to penile vasodilators. In this review, we discuss the connecting factors between obesity and ED and the possible combined treatment modalities.
\end{abstract}

Keywords: Erectile dysfunction; Metformin; Obesity; Phosphodiesterase 5 inhibitors

This is an Open Access article distributed under the terms of the Creative Commons Attribution Non-Commercial License (http://creativecommons.org/licenses/by-nc/4.0) which permits unrestricted non-commercial use, distribution, and reproduction in any medium, provided the original work is properly cited.

\section{INTRODUCTION}

Obesity is a major public health concern worldwide due to its rapidly increasing prevalence and the common association with various metabolic alterations, also known as metabolic syndrome. It is characterized by a collection of risk factors for cardiovascular disease and type 2 diabetes mellitus, such as abdominal obesity, an elevated level of triglycerides, hyperglycemia, elevated blood pressure, and low high-density lipoprotein [1].

Obesity is a key component of metabolic syndrome, and their components are linked to a clustering fea- ture, which is well-known as the common soil hypothesis. The main pathophysiologic processes of common soil are oxidative stress, inflammation, and insulin and leptin resistance (Table 1) [2,3]. Erectile dysfunction (ED) has recently become a concern as a factor of metabolic syndrome in men [4].

There is evidence from animal to human research supporting the association between obesity and ED. In particular, De Souza et al [5] reported that high caloric diet-induced ED resulted from endothelial damage in rats. A 14-year prospective study demonstrated that obesity is an independent risk factor for ED [6]. Fillo et

Received: Apr 12, 2018 Revised: May 17, 2018 Accepted: May 23, 2018 Published online July 25, 2018

Correspondence to: Yong Woon Kim iD https://orcid.org/0000-0003-2868-9690

Department of Physiology, Yeungnam University College of Medicine, 170 Hyeonchung-ro, Nam-gu, Daegu 42415, Korea.

Tel: +82-53-640-6922, Fax: +82-53-651-3651, E-mail: ywkim@med.yu.ac.kr 


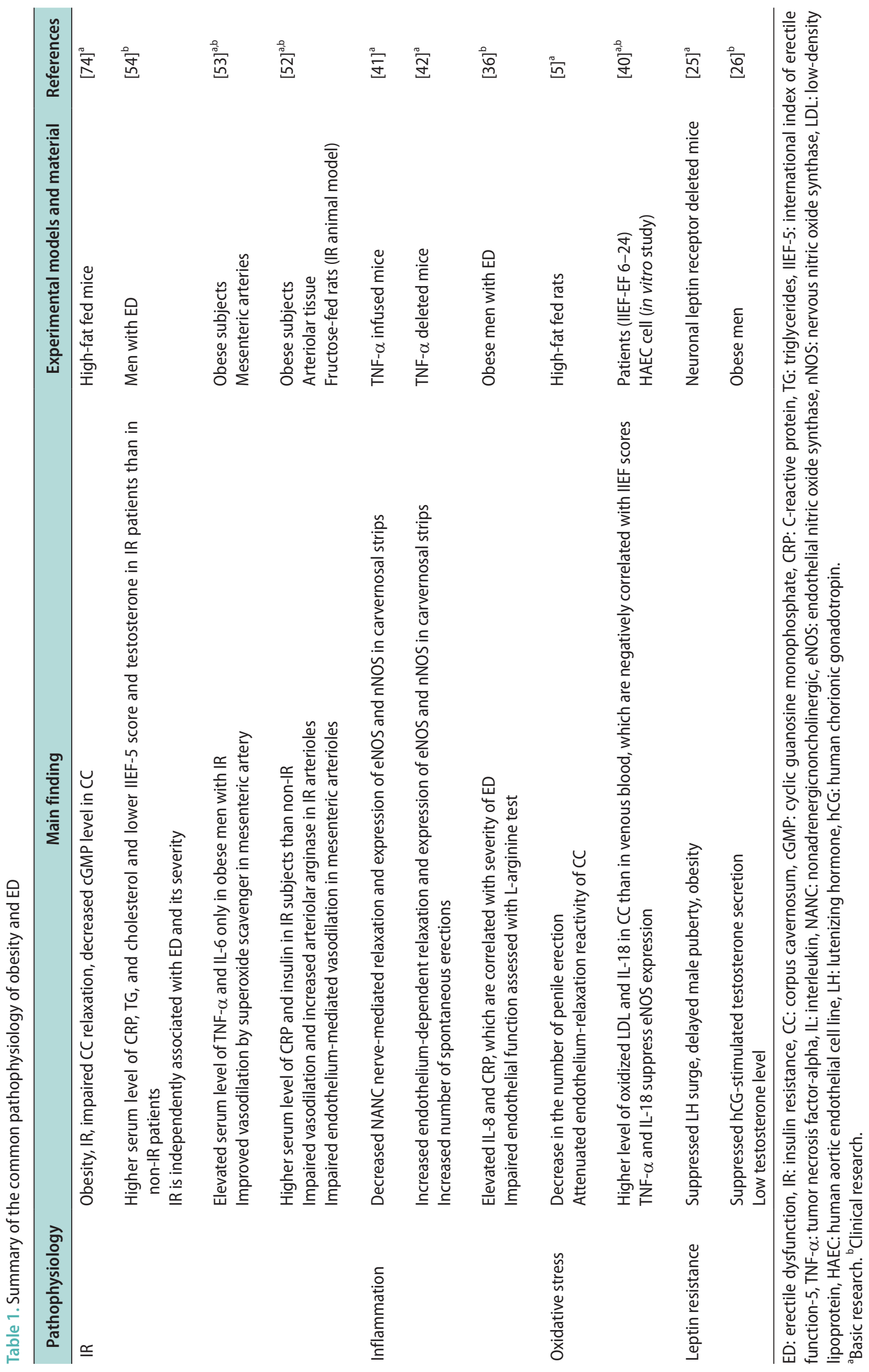


al [7] observed that men with abdominal obesity had a higher incidence rate of ED and the incidence rate was elevated in proportion to the degree of obesity. Moreover, the severity of ED has been shown to be correlated with comorbid medical conditions including obesity, which results in a reduced responsiveness to phosphodiesterase 5 (PDE5) inhibitors in severely obese patients [8]. Weight reduction with bariatric surgery has been reported to improve ED in obese men significantly [9]. An animal study demonstrated that bariatric surgery improves glucose tolerance and elevates intracavernosal pressure and endothelial nitric oxide synthase (eNOS) and nervous nitric oxide synthase (nNOS) expressions in Otsuka Long-Evans Tokushima fatty rats [10]. Moreover, Kun et al [11] observed that gastric bypass surgery decreases serum cholesterol and triglycerides levels and carvernosal intima-media thickness and increases endothelial function score in a clinical study. Lifestyle modification and exercise also improve ED [12-14]. The major connections between obesity and ED are derangements of hypothalamic regulation of the neuroendocrine system and endothelial dysfunction [15].

In this aspect, concomitant treatment of metabolic derangements associated with obesity in patients with ED who are obese would improve treatment efficacy in patients with ED and reduce the refractory response to penile vasodilators because obesity and ED may share common soil.

In this review, we discuss the linking factors between obesity and ED as well as possible combined treatment modalities.

\section{OBESITY}

Although obesity is induced when caloric intake chronically exceeds expenditure, its causes are complicated and heterogeneous. The human body has fine regulating mechanisms to control body weight homeostasis. However, these mechanisms often fail because of various causes, such as genetic, hormonal, psychological, metabolic, physical, and social defects [16].

The hypothalamus is the center for regulating body weight homeostasis and consists of various input signals such as leptin, insulin, ghrelin, and the autonomic nervous system. Output signals regulate appetite and thermogenesis [17]. The classic and most important input signal is the leptin circuit. Leptin, an $o b$ gene product secreted by adipose tissue acts on the hypothalamus, induces suppression of appetite and increases thermogenesis [18]. The mutation of the $o b$ gene or the leptin receptor leads to severe obesity, such as in $o b / o b$ and $d b / d b$ mice. However, the leptin concentration is elevated in obese rodents and humans owing to leptin resistance. In addition to body weight regulation, the hypothalamus also controls the endocrine system, reproduction, body temperature, and the autonomic nervous system [19].

\section{Leptin resistance and low testosterone level}

Obesity is not considered a pathologic condition of adipose tissue per se, but a systemic condition that affects various tissues from the hypothalamus to peripheral tissues. The main pathological features of obesity are elevated lipid concentrations in the blood; secretion of adipokines from hypertrophied adipocytes; and inflammatory responses due to the infiltration of immune cells into the adipose tissues, with resultant leptin and insulin resistance [18,20].

Elevated free fatty acids (FFA) induce lipotoxicity and oxidative stress in peripheral tissues as well as generate an inflammatory response in the hypothalamus the control center for metabolism and reproduction. The inflammatory response in the hypothalamus disturbs normal regulatory processes, such as neuroendocrine regulations and maintenance of leptin sensitivity [21]. Among these disturbances, the decreased secretion of gonadotropin-releasing hormone $(\mathrm{GnRH})$ associated with leptin resistance reduces the levels of testosterone, which is one of the causes of ED. Leptin resistance is a characteristic feature of obesity, and it is well known that leptin affects reproduction [19]. One of the possible mechanisms for leptin-resistanceinduced GnRH suppression in the hypothalamus is overexpression of agouti-related peptide and neuropeptide $\mathrm{Y}$, which results from a lack of inhibition by leptin and leads to the suppression of GnRH secretion in mice [22]. In addition to leptin's stimulatory effect on GnRH secretion, leptin inhibits testosterone secretion at the testicular level. Thus, obesity with leptin resistance and secondary hyperleptinemia shows lowered testosterone because of a weakened stimulatory effect of leptin on GnRH secretion and the inhibitory effect of leptin on testicular testosterone secretion [23]. Similarly, suppression of luteinizing hormone surge has been reported in leptin receptor-deficient obese Zucker rats [24] and 
neuronal leptin receptor deleted mice [25]. Moreover, human chorionic gonadotropin-stimulated testosterone secretion is suppressed in obese men [26].

Another mechanism for the low testosterone levels seen in obesity is that elevated aromatase by hypertrophied adipose tissue increases the conversion of testosterone to estradiol and elevated estradiol suppresses $\mathrm{GnRH}$ in the hypothalamus via a negative feedback mechanism [27].

In an epidemiology study, Knoblovits et al [28] studied the relationship between obesity and testosterone level and reported that body mass index (BMI) is negatively associated with the free testosterone level and erectile function. Moreover, testosterone replacement for 5 years has shown a progressive and sustainable reduction of body weight in obese subjects with hypogonadism [29], suggesting a close association between obesity and testosterone levels.

\section{Endothelial dysfunction and insulin resistance}

Another connection between obesity and ED is endothelial dysfunction due to obesity-associated derangements, such as elevated FFA level, adipokines, inflammation, and oxidative stress, and insulin resistance. The main features of endothelial dysfunction are reduced production of nitric oxide (NO), which result in difficulties in the smooth switch of vessels between dilation and constriction [30]. Chronic high-fat feeding induces endothelial dysfunction and ED in rodents [5]. We also previously demonstrated that high-fat feeding decreases penile eNOS expression in rats [31], and palmitate induces endothelial cell damage through reactive oxygen species (ROS) generation in vitro [32]. Taken together, the elevated FFA levels associated with high-fat feeding induces ROS elevation and NOS suppression via the downregulation of 5 '-adenosine monophosphate-activated protein kinase (AMPK)-phosphatidylinositol 3-kinase (PI3K)-eNOS pathway in the endothelium and results in decreased NO generation [30].

A possible process for induction of inflammation by elevated FFA is that FFA activates Toll-like receptors, an innate immune receptor, and trigger intracellular signaling molecules, such as myeloid differentiation primary response gene 88 and nuclear factor $\mathrm{kB}$; a transcription factor for pro-inflammatory cytokines, and consequentially produces inflammatory cytokines
[33,34], which suppress eNOS/NO pathway [35], then leads to endothelial dysfunction. Consistently, a human study demonstrated that C-reactive protein, a systemic inflammatory marker, is higher in obese men with ED than in obese men without ED and is correlated with the severity of ED [36]. These are supported that antiinflammatory agent protects ED in diabetic rats [37] and improves erectile function scores in a human study [38].

Adipokines are adipose tissue-driven cytokines. They involve various metabolic processes, such as energy metabolism, inflammatory response, and vascular function. In an obese state, adipokines are hyper- or hyposecreted and have a pro- or anti-inflammatory effect on vascular endothelium. This dysregulation of adipokine production results in the generation of ROS and induces endothelial dysfunction. Tumor necrosis factor-alpha (TNF- $\alpha$ ) and interleukin-6 are major pro-inflammatory cytokines produced by hypertrophied adipocytes. They induce inflammatory gene transcript in endothelial cells [39] and suppresses eNOS expression [40]. Corpora cavernosa from TNF- $\alpha$-infused mice shows attenuated nonadrenergic-noncholinergic nerve-mediated relaxation and suppressed eNOS and nNOS gene expression [41]. Moreover, TNF- $\alpha$ depleted mice show increased endothelium-dependent relaxation in isolated corpora cavernosa and elevated eNOS and nNOS expression [42]. In human studies, plasma levels of these inflammatory cytokines are correlated with BMI and generate inflammatory reaction and insulin resistance [43] and high levels of TNF- $\alpha$ were significantly associated with ED [44].

Adiponectin, one of the most abundant hormones produced mainly by adipose tissue, is differently regulated by obesity than other adipokines, and the concentration is decreased in an obese state [45]. Adiponectin has anti-diabetic, anti-inflammatory, anti-atherogenic effects, as well as insulin-sensitizing effects on the vascular endothelium [46]. Adiponectin attenuates the production of ROS induced by palmitate in endothelial cells [47]. Adiponectin also increases phospho-eNOS in endothelial cells, and adiponectin knockout mice have shown impaired endothelium-dependent vasodilation [48]. Thus, decreased adiponectin levels in obesity induce insulin resistance, proinflammatory activation, and finally endothelial dysfunction. These alterations of adipokines are strongly associated with obesity because weight reduction from exercise, diet, or surgery 
reverses these pathological conditions [49,50].

Insulin induces vasodilation through increased expression of eNOS and NO production via the activation of PI3K-Akt pathways [51]. Thus insulin resistance, which is commonly associated with obesity, plays a role between obesity and NO deficiency [52]. This is supported by a human study that demonstrated obesity without insulin resistance preserved endothelial function while insulin-resistant obese individuals had endothelial dysfunction [53]. A clinical study also showed that insulin resistance is an independent determinant of ED in young adult men [54]. Insulin resistance elevates oxidative stress and inflammatory cytokines in endothelial cells, which decreases NO bioavailability, and induces endothelial dysfunction [55,56].

\section{ERECTILE DYSFUNCTION}

$\mathrm{ED}$ is a frequent medical consequence in the elderly. Its pathologic features are classified as psychogenic and organic in origin. Organic ED is vasculogenic, neurogenic, anatomic, and endocrinologic origin. Vasculogenic ED, the most common form, mainly results from endothelial dysfunction. Moreover, cases of vasculogenic ED have been shown to be more closely associated with obesity and associating hormonal alterations, compared with other cases of ED [57]. PDE5 inhibitors are the most widely prescribed medicine for patients with ED. Currently available PDE5 inhibitors are sildenafil (Viagra; Pfizer, New York City, NY, USA), vardenafil (Levitra, Staxyn), tadalafil (Cialis; Eli Lilly), avanafil (Stendra; VIVUS Inc., Campbell, CA, USA), udenafil (Zydena; Dong-A PharmTech, Seoul, Korea), and mirodenafil (Mvix; SK Chemical, Seongnam, Korea) [58].

As described above, ED is associated with obesity and its concomitant metabolic derangements. High-fat dietinduced obese rodents are commonly used as an animal model for ED [59], whereas acute correction of obesity by bariatric surgery improves ED [9,11]. These findings suggest a causal relationship between obesity and ED.

In a study from Slovakia, $73 \%$ of men older than 40-years-old with abdominal obesity had some degree of ED [60]. In another study, 79\% of men presenting with ED had a BMI of $25 \mathrm{~kg} / \mathrm{m}^{2}$ or higher and obese men, over $30 \mathrm{~kg} / \mathrm{m}^{2}$, had 3 times greater risk for sexual dysfunction than the general population [61]. Furthermore, the degree of $\mathrm{ED}$ in obese patients is more severe than that in non-obese patients, resulting an increased refractory rate to PDE5 inhibitors in severely obese patients [15]. According to a meta-analysis, the overall refractory rate for sildenafil, tadalafil, and vardenafil is $30 \%$ to $35 \%$, which is reduced to less than $20 \%$ when improving comorbid conditions [62].

\section{COMBINED TREATMENT WITH METFORMIN AND PHOSPHODIESTERASE 5 INHIBITORS}

As described above, obesity and ED may share common features including obesity-associated metabolic alterations. Among them, insulin and leptin resistance are central pathologic conditions inducing ED [63]. Their amelioration would be helpful to treat patients with ED. Metformin originally was developed as an insulin sensitizer six decades ago. Currently, it has been reported that metformin also improves leptin resistance $[18,64,65]$. Therefore, metformin has become a strong candidate to normalize obesity-associated pathologic internal environments and resulting potentiation of the efficacy of ED treatment with PDE5 inhibitors. In this aspect, we discuss combined treatment of metformin and PDE5 inhibitors.

\section{Metformin's effect on erectile dysfunction}

Metformin is an anti-diabetic agent that been shown to have anti-inflammatory [66] and anti-obesity effects $[18,64,65]$. Although Rey-Valzacchi et al [67] hypothesized that its beneficial effect on cavernosal NO signaling resulted from improving metabolic profile, the vascular change by metformin was induced even when there is no significant glycemic control effect by metformin in streptozotocin-diabetic rats [68]. This suggests that metformin has a primary and secondary effect on vessels.

The major target molecule of metformin is AMPK, a cellular energy sensing molecule activated under an energy deprivation state. Although the molecular mechanism of metformin is not completely understood, AMPK has been shown to mediate diverse biological effects on the endothelium, such as activating NOS [31], reducing oxidative stress [32], elevating FFA oxidation, and suppressing endoplasmic reticulum stress [69]. Chantler et al [70] also demonstrated that metformin preserved the bioavailability of vascular NO in the 
abdominal aorta of obese Zucker rats by improving insulin resistance, which is a cause of NO deficiency [2]. In another study, metformin was shown to reverse intracavernosal muscle tone and elevate eNOS phosphorylation in an angiotensin II-induced ED model [71].

Because obesity is frequently associated with a chronic low-grade inflammatory state and related conditions, including ED and atherosclerosis, suppression of inflammation may improve ED. Rodent and human studies have reported that metformin has positive effects on the endothelium. In particular, Jing et al [72] presented that metformin improves obesity-associated inflammation by altering macrophage polarization. Metformin may protect against coronary atherosclerosis in prediabetes and early diabetes mellitus among men [73]. Silva et al [74] reported that metformin improves ED in obese mice by improving in vitro endothelial and nitrergic cavernosal relaxation. Vignozzi et al [75] reported that metformin increases adenosine signaling in HF-fed rabbits. Vitale et al [76] demonstrated that metformin improves endothelial-dependent vasodilation in patients with metabolic syndrome. Moreover, Giagulli et al [77] have shown that metformin treatment combined with testosterone boosts erectile function in patients with obesity and hypogonadism.

\section{Systemic beneficial effects of \\ phosphodiesterase 5 inhibitors}

PDE5 inhibitors are widely prescribed for the treatment of patients with ED. PDE5 inhibition prevents the degradation of cyclic guanosine monophosphate and elevates NO bioavailability [78]. In addition, numerous studies have reported that PDE5 inhibitors have beneficial systemic effects. It is well established that PDE5 inhibitors have anti-inflammatory effects based on studies ranging from rodents to humans [7981]. Nunes et al [80] suggested that AMPK, a major target molecule of metformin, was associated with the anti-inflammatory effects seen in sildenafil. Santi et al [81] demonstrated that PDE5 inhibition improves endothelial inflammatory parameters in patients with diabetes and ED. De Toni et al [82] reported that vardenafil elevates mitochondrial biogenesis via the activation of peroxisome proliferator-activated receptor-y and adiponectin in human adipose tissue ex vivo.

Moreover, sildenafil therapy lasting 12 weeks reduced visceral fat in humans and murine models of diabetes [83]. PDE5 inhibition in sildenafil also enhanc- es insulin sensitivity in human umbilical endothelial cells [84] and overweight individuals with prediabetes assessed by the hyperglycemic clamp technique [85]. Although Ho et al [86] fail to show improvements in insulin resistance with tadalafil in obese individuals, they demonstrate a favorable effect on $\beta$-cell compensation by tadalafil.

Recently we also demonstrated that udenafil has weight loss effects in high fat-fed obese mice and directly suppresses hypothalamic Toll-like receptor 4 , a receptor trailing proinflammatory responses and activated by long chain fatty acids [34]. Furthermore, it was reported that PDE5 inhibitors lowered the risk of overall mortality in patients with type 2 diabetes in a retrospective cohort study [87].

\section{Combination of phosphodiesterase 5 inhibitors and metformin}

It has been established that obesity and ED share an internal pathological environment, thus, targeting obesity as an underlying factor of ED may be an important therapeutic approach to maximize the efficacy of treatment. Moreover, once daily prescription for a long time with low dose PDE5 inhibitors is settled down as a trend of ED treatment currently [78]. It has become increasingly important to focus on the systemic and metabolic effects of PDE5 inhibitors, especially in patients with ED and comorbid medical conditions. Combination therapy would be helpful and efficient in this respect.

Although data on the clinical effect of combined treatment of metformin and PDE5 inhibitor are lacking, several studies have evaluated the combined effects of metformin and PDE5 inhibitors. In a prospective, randomized, double-blind study, researchers demonstrated that the addition of metformin to sildenafil improved erectile function in patients with $\mathrm{ED}$, a poor response to sildenafil, and insulin resistance [67]. They postulated that the beneficial effects of metformin result from the improvement of insulin resistance because PDE5 inhibitors require adequate levels of NO to be effective and insulin resistant states have decreased NO levels. Similarly, Giagulli et al [77] reported that combined treatment metformin with testosterone improves ED considerably and lowers body weight in men with diabetes who are obese. Park et al [3] observed that atorvastatin partially improves erectile function in streptozotocin-induced diabetic rats 
and recommended combination therapy to treat severe diabetes-associated ED.

However, an animal study demonstrated that sildenafil blocked metformin's vasodilatory effect in freshly-isolated rat tail arteries [88]. Another combination treatment with anti-hypertensive drugs was shown to not significantly affect the efficacy of udenafil [89].

Further study is needed to evaluate the combination treatment with PDE5 inhibitors and metformin.

\section{CONCLUSIONS}

To maximize the efficacy of treatment in patients with ED who are obese, managing obesity as an underline disease for ED is an important therapeutic approach because obesity and ED share an internal pathological environment. The long-term once daily administration of low-dose PDE5 inhibitors rather than on demand prescription has recently become popular. Thus, we have to focus on the systemic and metabolic effects of PDE5 inhibitors and recommend combination therapy.

Although there is not enough research to evaluate the clinical effect of combined treatment of PDE5 inhibitors and metformin in patients with ED who are obese, several studies have reported optimistic outcomes, and combination therapy is strongly recommended especially in severe systemic disease-associated ED. Further studies are warranted.

\section{Disclosure}

The authors have no potential conflicts of interest to disclose.

\section{Author Contribution}

Research conception \& design: Kim YW, Moon KH. Data acquisition: Kim YW, Park SY. Data analysis and interpretation: all authors. Drafting of the manuscript: Kim YW, Moon KH. Critical revision of the manuscript: Park SY. Approval of final manuscript: all authors.

\section{REFERENCES}

1. Malik S, Wong ND, Franklin SS, Kamath TV, L'Italien GJ, Pio JR, et al. Impact of the metabolic syndrome on mortality from coronary heart disease, cardiovascular disease, and all causes in United States adults. Circulation 2004;110:1245-50.
2. Cersosimo E, DeFronzo RA. Insulin resistance and endothelial dysfunction: the road map to cardiovascular diseases. Diabetes Metab Res Rev 2006;22:423-36.

3. Park J, Kwon OS, Cho SY, Paick JS, Kim SW. Chronic administration of atorvastatin could partially ameliorate erectile function in streptozotocin-induced diabetic rats. PLoS One 2017;12:e0172751.

4. Corona G, Rastrelli G, Morelli A, Vignozzi L, Mannucci E, Maggi M. Hypogonadism and metabolic syndrome. J Endocrinol Invest 2011;34:557-67.

5. de Souza ILL, Barros BC, de Oliveira GA, Queiroga FR, Toscano LT, Silva AS, et al. Hypercaloric diet establishes erectile dysfunction in rat: mechanisms underlying the endothelial damage. Front Physiol 2017;8:760.

6. Bacon CG, Mittleman MA, Kawachi I, Giovannucci E, Glasser DB, Rimm EB. A prospective study of risk factors for erectile dysfunction. J Urol 2006;176:217-21.

7. Fillo J, Levcikova M, Ondrusova M, Breza J, Labas P. Importance of different grades of abdominal obesity on testosterone level, erectile dysfunction, and clinical coincidence. Am J Mens Health 2017;11:240-5.

8. Demir O, Akgul K, Akar Z, Cakmak O, Ozdemir I, Bolukbasi A, et al. Association between severity of lower urinary tract symptoms, erectile dysfunction and metabolic syndrome. Aging Male 2009;12:29-34.

9. Aleid M, Muneer A, Renshaw S, George J, Jenkinson AD, Adamo M, et al. Early effect of bariatric surgery on urogenital function in morbidly obese men. J Sex Med 2017;14:205-14.

10. Choi YS, Lee SK, Bae WJ, Kim SJ, Cho HJ, Hong SH, et al. Bariatric surgery improves the cavernosal neuronal, vasorelaxation, and contraction mechanisms for erectile dysfunction as result of amelioration of glucose homeostasis in a diabetic rat model. PLoS One 2014;9:e104042.

11. Kun L, Pin Z, Jianzhong D, Xiaodong H, Haoyong Y, Yuqian $B$, et al. Significant improvement of erectile function after Roux-en-Y gastric bypass surgery in obese Chinese men with erectile dysfunction. Obes Surg 2015;25:838-44.

12. Hannan JL, Maio MT, Komolova M, Adams MA. Beneficial impact of exercise and obesity interventions on erectile function and its risk factors. J Sex Med 2009;6 Suppl 3:254-61.

13. Meldrum DR, Gambone JC, Morris MA, Esposito K, Giugliano D, Ignarro LJ. Lifestyle and metabolic approaches to maximizing erectile and vascular health. Int J Impot Res 2012;24:61-8

14. Maiorino MI, Bellastella G, Esposito K. Lifestyle modifications and erectile dysfunction: what can be expected? Asian J Androl 2015;17:5-10.

15. Patel JP, Lee EH, Mena CI, Walker CN. Effects of metformin 
on endothelial health and erectile dysfunction. Transl Androl Urol 2017;6:556-65.

16. Roh E, Song DK, Kim MS. Emerging role of the brain in the homeostatic regulation of energy and glucose metabolism. Exp Mol Med 2016;48:e216.

17. Kim YW, Choi DW, Park YH, Huh JY, Won KC, Choi KH, et al. Leptin-like effects of MTII are augmented in MSG-obese rats. Regul Pept 2005;127:63-70.

18. Kim YW, Kim JY, Park YH, Park SY, Won KC, Choi KH, et al. Metformin restores leptin sensitivity in high-fat-fed obese rats with leptin resistance. Diabetes 2006;55:716-24.

19. Small CJ, Stanley SA, Bloom SR. Appetite control and reproduction: leptin and beyond. Semin Reprod Med 2002;20:38998.

20. Shimobayashi M, Albert V, Woelnerhanssen B, Frei IC, Weissenberger D, Meyer-Gerspach AC, et al. Insulin resistance causes inflammation in adipose tissue. J Clin Invest 2018;128:1538-50.

21. de Git KC, Adan RA. Leptin resistance in diet-induced obesity: the role of hypothalamic inflammation. Obes Rev 2015;16:207-24.

22. Egan OK, Inglis MA, Anderson GM. Leptin signaling in AgRP neurons modulates puberty onset and adult fertility in mice. J Neurosci 2017;37:3875-86.

23. Costanzo PR, Knoblovits P. Male gonadal axis function in patients with type 2 diabetes. Horm Mol Biol Clin Investig 2016;26:129-34.

24. Nakao K, Iwata K, Takeshita T, Ozawa H. Expression of hypothalamic kisspeptin, neurokinin B, and dynorphin A neurons attenuates in female Zucker fatty rats. Neurosci Lett 2018;665:135-9.

25. Quennell JH, Mulligan AC, Tups A, Liu X, Phipps SJ, Kemp $\mathrm{CJ}$, et al. Leptin indirectly regulates gonadotropin-releasing hormone neuronal function. Endocrinology 2009;150:280512 .

26. Isidori AM, Caprio M, Strollo F, Moretti C, Frajese G, Isidori A, et al. Leptin and androgens in male obesity: evidence for leptin contribution to reduced androgen levels. J Clin Endocrinol Metab 1999;84:3673-80.

27. Williams G. Aromatase up-regulation, insulin and raised intracellular oestrogens in men, induce adiposity, metabolic syndrome and prostate disease, via aberrant ER- $\alpha$ and GPER signalling. Mol Cell Endocrinol 2012;351:269-78.

28. Knoblovits P, Costanzo PR, Valzacchi GJ, Gueglio G, Layus AO, Kozak AE, et al. Erectile dysfunction, obesity, insulin resistance, and their relationship with testosterone levels in eugonadal patients in an andrology clinic setting. J Androl 2010;31:263-70.
29. Saad F, Yassin A, Doros G, Haider A. Effects of long-term treatment with testosterone on weight and waist size in 411 hypogonadal men with obesity classes I-III: observational data from two registry studies. Int J Obes (Lond) 2016;40:16270

30. Ghosh A, Gao L, Thakur A, Siu PM, Lai CWK. Role of free fatty acids in endothelial dysfunction. J Biomed Sci 2017;24:50.

31. Kim YW, Park SY, Kim JY, Huh JY, Jeon WS, Yoon CJ, et al. Metformin restores the penile expression of nitric oxide synthase in high-fat-fed obese rats. J Androl 2007;28:555-60.

32. Kim JE, Kim YW, Lee IK, Kim JY, Kang YJ, Park SY. AMPactivated protein kinase activation by 5 -aminoimidazole4-carboxamide-1-beta-D-ribofuranoside (AICAR) inhibits palmitate-induced endothelial cell apoptosis through reactive oxygen species suppression. J Pharmacol Sci 2008;106:394403.

33. Kim F, Tysseling KA, Rice J, Pham M, Haji L, Gallis BM, et al. Free fatty acid impairment of nitric oxide production in endothelial cells is mediated by IKKbeta. Arterioscler Thromb Vasc Biol 2005;25:989-94.

34. Ryu SY, Choi YJ, Park SY, Kim JY, Kim YD, Kim YW. Udenafil, a phosphodiesterase 5 inhibitor, reduces body weight in high-fat-fed mice. World J Mens Health 2018;36:41-9.

35. Li S, Xu J, Yao W, Li H, Liu Q, Xiao F, et al. Sevoflurane pretreatment attenuates TNF- $\alpha$-induced human endothelial cell dysfunction through activating eNOS/NO pathway. Biochem Biophys Res Commun 2015;460:879-86.

36. Giugliano F, Esposito K, Di Palo C, Ciotola M, Giugliano G, Marfella R, et al. Erectile dysfunction associates with endothelial dysfunction and raised proinflammatory cytokine levels in obese men. J Endocrinol Invest 2004;27:665-9.

37. Hafez G, Gonulalan U, Kosan M, Arioglu E, Ozturk B, Cetinkaya $\mathrm{M}$, et al. Acetylsalicylic acid protects erectile function in diabetic rats. Andrologia 2014;46:997-1003.

38. Bayraktar Z, Albayrak S. Antiplatelet (aspirin) therapy as a new option in the treatment of vasculogenic erectile dysfunction: a prospective randomized double-blind placebocontrolled study. Int Urol Nephrol 2018;50:411-8.

39. Mong PY, Petrulio C, Kaufman HL, Wang Q. Activation of Rho kinase by TNF-alpha is required for JNK activation in human pulmonary microvascular endothelial cells. J Immunol 2008;180:550-8.

40. Roumeguère T, Van Antwerpen P, Fathi H, Rousseau A, Vanhamme L, Franck T, et al. Relationship between oxidative stress and erectile function. Free Radic Res 2017;51:924-31.

41. Carneiro FS, Zemse S, Giachini FR, Carneiro ZN, Lima VV, Webb RC, et al. TNF-alpha infusion impairs corpora caver- 
nosa reactivity. J Sex Med 2009;6 Suppl 3:311-9.

42. Carneiro FS, Sturgis LC, Giachini FR, Carneiro ZN, Lima VV, Wynne BM, et al. TNF-alpha knockout mice have increased corpora cavernosa relaxation. J Sex Med 2009;6:115-25.

43. Van de Voorde J, Pauwels B, Boydens C, Decaluwé K. Adipocytokines in relation to cardiovascular disease. Metabolism 2013;62:1513-21.

44. Matos G, Hirotsu C, Alvarenga TA, Cintra F, Bittencourt L, Tufik S, et al. The association between TNF- $\alpha$ and erectile dysfunction complaints. Andrology 2013;1:872-8.

45. Arita Y, Kihara S, Ouchi N, Takahashi M, Maeda K, Miyagawa J, et al. Paradoxical decrease of an adipose-specific protein, adiponectin, in obesity. Biochem Biophys Res Commun 1999;257:79-83.

46. Achari AE, Jain SK. Adiponectin, a therapeutic target for obesity, diabetes, and endothelial dysfunction. Int J Mol Sci 2017;18:E1321.

47. Kim JE, Song SE, Kim YW, Kim JY, Park SC, Park YK, et al. Adiponectin inhibits palmitate-induced apoptosis through suppression of reactive oxygen species in endothelial cells: involvement of cAMP/protein kinase A and AMP-activated protein kinase. J Endocrinol 2010;207:35-44.

48. Ouchi N, Ohishi M, Kihara S, Funahashi T, Nakamura T, Nagaretani H, et al. Association of hypoadiponectinemia with impaired vasoreactivity. Hypertension 2003;42:231-4.

49. Gentili A, Zaibi MS, Alomar SY, De Vuono S, Ricci MA, Alaeddin A, et al. Circulating levels of the adipokines monocyte chemotactic protein-4 (MCP-4), macrophage inflammatory protein-1 $\beta$ (MIP-1 $\beta$ ), and eotaxin-3 in severe obesity and following bariatric surgery. Horm Metab Res 2016;48:847-53.

50. Arent SM, Walker AJ, Pellegrino JK, Sanders DJ, McFadden BA, Ziegenfuss TN, et al. The combined effects of exercise, diet, and a multi-ingredient dietary supplement on body composition and adipokine changes in overweight adults. J Am Coll Nutr 2018;37:111-20.

51. Zeng G, Nystrom FH, Ravichandran LV, Cong LN, Kirby M, Mostowski H, et al. Roles for insulin receptor, PI3-kinase, and Akt in insulin-signaling pathways related to production of nitric oxide in human vascular endothelial cells. Circulation 2000;101:1539-45.

52. El Assar M, Angulo J, Santos-Ruiz M, Ruiz de Adana JC, Pindado ML, Sánchez-Ferrer A, et al. Asymmetric dimethylarginine (ADMA) elevation and arginase up-regulation contribute to endothelial dysfunction related to insulin resistance in rats and morbidly obese humans. J Physiol 2016;594:304560.

53. El Assar M, Ruiz de Adana JC, Angulo J, Pindado Martínez ML, Hernández Matías A, Rodríguez-Mañas L. Preserved en- dothelial function in human obesity in the absence of insulin resistance. J Transl Med 2013;11:263.

54. Chen S, Wu R, Huang Y, Zheng F, Ou Y, Tu X, et al. Insulin resistance is an independent determinate of ED in young adult men. PLoS One 2013;8:e83951.

55. Pierce GL, Lesniewski LA, Lawson BR, Beske SD, Seals DR. Nuclear factor-\{kappa\}B activation contributes to vascular endothelial dysfunction via oxidative stress in overweight/obese middle-aged and older humans. Circulation 2009;119:128492.

56. Hwang $\mathrm{MH}$, Lee $\mathrm{S}$. Insulin resistance: vascular function and exercise. Integr Med Res 2016;5:198-203.

57. Dozio E, Barassi A, Dogliotti G, Malavazos AE, Colpi GM, D'Eril GV, et al. Adipokines, hormonal parameters, and cardiovascular risk factors: similarities and differences between patients with erectile dysfunction of arteriogenic and nonarteriogenic origin. J Sex Med 2012;9:2370-7.

58. Zhang WH, Zhang XH. Clinical and preclinical treatment of urologic diseases with phosphodiesterase isoenzymes 5 inhibitors: an update. Asian J Androl 2016;18:723-31.

59. Kapoor MS, Khan SA, Gupta SK, Choudhary R, Bodakhe SH. Animal models of erectile dysfunction. J Pharmacol Toxicol Methods 2015;76:43-54.

60. Fillo J, Breza J, Levčíkova M, Luha J, Vachulova A, Durdík Š, et al. Occurrence of erectile dysfunction, testosterone deficiency syndrome and metabolic syndrome in patients with abdominal obesity. Where is a sufficient level of testosterone? Int Urol Nephrol 2012;44:1113-20.

61. Kaya E, Sikka SC, Gur S. A comprehensive review of metabolic syndrome affecting erectile dysfunction. J Sex Med 2015;12:856-75.

62. McMahon CN, Smith CJ, Shabsigh R. Treating erectile dysfunction when PDE5 inhibitors fail. BMJ 2006;332:589-92.

63. Faulkner LD, Dowling AR, Stuart RC, Nillni EA, Hill JW. Reduced melanocortin production causes sexual dysfunction in male mice with POMC neuronal insulin and leptin insensitivity. Endocrinology 2015;156:1372-85.

64. Malin SK, Kashyap SR. Effects of metformin on weight loss: potential mechanisms. Curr Opin Endocrinol Diabetes Obes 2014;21:323-9.

65. Pastor-Villaescusa B, Cañete MD, Caballero-Villarraso J, Hoyos R, Latorre M, Vázquez-Cobela R, et al. Metformin for obesity in prepubertal and pubertal children: a randomized controlled trial. Pediatrics 2017;140:e20164285.

66. Saisho Y. Metformin and inflammation: its potential beyond glucose-lowering effect. Endocr Metab Immune Disord Drug Targets 2015;15:196-205.

67. Rey-Valzacchi GJ, Costanzo PR, Finger LA, Layus AO, Gueg- 
lio GM, Litwak LE, et al. Addition of metformin to sildenafil treatment for erectile dysfunction in eugonadal nondiabetic men with insulin resistance. A prospective, randomized, double-blind pilot study. J Androl 2012;33:608-14.

68. Majithiya JB, Balaraman R. Metformin reduces blood pressure and restores endothelial function in aorta of streptozotocin-induced diabetic rats. Life Sci 2006;78:2615-24.

69. García-Prieto CF, Gil-Ortega M, Aránguez I, Ortiz-Besoain M, Somoza B, Fernández-Alfonso MS. Vascular AMPK as an attractive target in the treatment of vascular complications of obesity. Vascul Pharmacol 2015;67-69:10-20.

70. Chantler PD, Shrader CD, Tabone LE, d'Audiffret AC, Huseynova $\mathrm{K}$, Brooks SD, et al. Cerebral cortical microvascular rarefaction in metabolic syndrome is dependent on insulin resistance and loss of nitric oxide bioavailability. Microcirculation 2015;22:435-45.

71. Labazi H, Wynne BM, Tostes R, Webb RC. Metformin treatment improves erectile function in an angiotensin II model of erectile dysfunction. J Sex Med 2013;10:2154-64.

72. Jing Y, Wu F, Li D, Yang L, Li Q, Li R. Metformin improves obesity-associated inflammation by altering macrophages polarization. Mol Cell Endocrinol 2018;461:256-64.

73. Goldberg RB, Aroda VR, Bluemke DA, Barrett-Connor E, Budoff M, Crandall JP, et al. Effect of long-term metformin and lifestyle in the diabetes prevention program and its outcome study on coronary artery calcium. Circulation 2017;136:5264.

74. Silva FH, Alexandre EC, Calmasini FB, Calixto MC, Antunes E. Treatment with metformin improves erectile dysfunction in a murine model of obesity associated with insulin resistance. Urology 2015;86:423.e1-6.

75. Vignozzi L, Filippi S, Comeglio P, Cellai I, Morelli A, Rastrelli $\mathrm{G}$, et al. Metformin in vitro and in vivo increases adenosine signaling in rabbit corpora cavernosa. J Sex Med 2014;11:1694-708.

76. Vitale C, Mercuro G, Cornoldi A, Fini M, Volterrani M, Rosano GM. Metformin improves endothelial function in patients with metabolic syndrome. J Intern Med 2005;258:250-6.

77. Giagulli VA, Carbone MD, Ramunni MI, Licchelli B, De Pergola G, Sabbà C, et al. Adding liraglutide to lifestyle changes, metformin and testosterone therapy boosts erectile function in diabetic obese men with overt hypogonadism. Andrology 2015;3:1094-103.

78. Moon KH, Kim SW, Moon du G, Kim JJ, Park NC, Lee SW, et al. A phase 3 study to evaluate the 1-year efficacy and safety of udenafil $75 \mathrm{mg}$ once daily in patients with erectile dysfunction. J Sex Med 2016;13:1263-9.

79. Varma A, Das A, Hoke NN, Durrant DE, Salloum FN, Kukreja RC. Anti-inflammatory and cardioprotective effects of tadalafil in diabetic mice. PLoS One 2012;7:e45243.

80. Nunes AK, Rapôso C, Rocha SW, Barbosa KP, Luna RL, da Cruz-Höfling MA, et al. Involvement of AMPK, IK $\beta \alpha-\mathrm{NF \kappa B}$ and eNOS in the sildenafil anti-inflammatory mechanism in a demyelination model. Brain Res 2015;1627:119-33.

81. Santi D, Granata AR, Guidi A, Pignatti E, Trenti T, Roli L, et al. Six months of daily treatment with vardenafil improves parameters of endothelial inflammation and of hypogonadism in male patients with type 2 diabetes and erectile dysfunction: a randomized, double-blind, prospective trial. Eur J Endocrinol 2016;174:513-22.

82. De Toni L, Strapazzon G, Gianesello L, Caretta N, Pilon C, Bruttocao A, et al. Effects of type 5-phosphodiesterase inhibition on energy metabolism and mitochondrial biogenesis in human adipose tissue ex vivo. J Endocrinol Invest 2011;34:738-41.

83. Fiore D, Gianfrilli D, Giannetta E, Galea N, Panio G, di Dato C, et al. PDE5 inhibition ameliorates visceral adiposity targeting the miR-22/SIRT1 pathway: evidence from the CECSID trial. J Clin Endocrinol Metab 2016;101:1525-34.

84. Mammi C, Pastore D, Lombardo MF, Ferrelli F, Caprio M, Consoli C, et al. Sildenafil reduces insulin-resistance in human endothelial cells. PLoS One 2011;6:e14542.

85. Ramirez CE, Nian H, Yu C, Gamboa JL, Luther JM, Brown NJ, et al. Treatment with sildenafil improves insulin sensitivity in prediabetes: a randomized, controlled trial. J Clin Endocrinol Metab 2015;100:4533-40.

86. Ho JE, Arora P, Walford GA, Ghorbani A, Guanaga DP, Dhakal BP, et al. Effect of phosphodiesterase inhibition on insulin resistance in obese individuals. J Am Heart Assoc 2014;3:e001001.

87. Anderson SG, Hutchings DC, Woodward M, Rahimi K, Rutter MK, Kirby M, et al. Phosphodiesterase type-5 inhibitor use in type 2 diabetes is associated with a reduction in allcause mortality. Heart 2016;102:1750-6.

88. Peuler JD, Phelps LE. Sildenafil does not enhance but rather attenuates vasorelaxant effects of antidiabetic agents. J Smooth Muscle Res 2015;51:22-36.

89. Cho MC, Paick JS. Udenafil for the treatment of erectile dysfunction. Ther Clin Risk Manag 2014;10:341-54. 